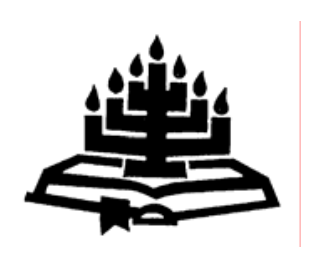

\title{
Sketse van 'n pastoraat van narratiewe betrokkenheid in die Lukasevangelie met besondere klem op die Saggeusverhaal
}

\author{
J.-A. van den Berg \& R.de Wet \\ Departement Praktiese Teologie \\ Universiteit van die Vrystaat \\ BLOEMFONTEIN \\ E-pos: vdbergja.hum@ufs.ac.za \\ roelfdewet@absamail.co.za
}

\begin{abstract}
Images of a pastorate of narrative engagement in the Gospel of Luke with special reference to the story of Zacchaeus

Important new developments have occurred during the last few decades within practical theology and in particular within pastoral theology. The article illustrates that narrative passages in Scripture can depict the meaning of these newer developments. Images portraying the spiritual life in the Gospel of Luke and in particular the story of Zacchaeus are explored under the headings: background to a pastoral engagement, an ecohermeneutic approach in a pastorate of narrative engagement, a spiralling pastoral engagement, and stories that fit. The story of a narrative pastoral engagement unfolds in a circular model, integrating paradigmatic-, epistemological- and methodological matters. An eco-hermeneutical approach closely linked to a pastorate of narrative engagement is followed within the designated epistemology. Social constructionism is augmented to become co-constructionism, thus providing for the recognition of truth as revealed in Scripture. Exemplary of this is that in a life-changing metamorphosis, Zacchaeus' saturated dominant story is replaced by a liberating thickened alternative story.
\end{abstract}

\section{Opsomming}

Sketse van 'n pastoraat van narratiewe betrokkenheid in die Lukasevangelie met besondere klem op die Saggeusverhaal

Belangrike nuwe ontwikkelings het die afgelope dekades binne die praktiese teologie en in besonder die pastorale teologie plaasgevind. Met die veronderstelling dat hierdie ontwikkelings 
ook deur die Woord ondersteun word, word die betekenis van 'n narratiewe pastorale betrokkenheid op 'n besondere wyse geïllustreer, aan die hand van die Evangelie van Lukas en in besonder die verhaal van Saggeus. Die betekenis daarvan vir die pastoraat word onder die volgende opskrifte ontgin: agtergrond tot pastorale betrokkenheid, die eko-hermeneutiese benadering in 'n pastoraat van narratiewe betrokkenheid, 'n spiralende pastorale betrokkenheid en verhale wat pas. In 'n hermeneutiese proses word paradigmatiese-, epistemologiese- en metodologiese oorwegings in 'n geïntegreerde sirkulêre model aan die orde gestel. Voortspruitend uit 'n eko-hermeneutiese ontwikkeling in die pastoraat word 'n epistemologie van narratiewe betrokkenheid gevolg. Deur ko-konstruksionisme as verdere aksent in die sosiale konstruksionisme te plaas, word die rol van die Skrif verder beskryf. In 'n voortdurende sirkulêre beweging tussen praktyk en teorie word teoretiese perspektiewe gekaats teen die verhaal van Saggeus.

\section{Inleiding}

Belangrike nuwe ontwikkelings het die afgelope dekades in die pastorale teorievorming plaasgevind, (Louw, 1999:21-27; Louw, 2003:36) met besondere klem op pastorale terapie (Stone, 2001:185-193; Immink, 2003:224-228; Scholtz, 2005:140-141; Van den Berg, 2006:164; Demasure \& Müller, 2006:410). Dit is egter 'n feit dat die soeke na 'n verantwoorde en deurleefde integrasie tussen konteks en Bybelse beginsels (Müller, 2005:76) steeds 'n uitdaging vir 'n Bybels-verantwoordbare pastoraat is (Van den Berg, 2006:178). Die belang van dié korrelasie tussen T(t)eks en konteks vir die pastoraat blyk duidelik wanneer Louw (2003:49) sê:

Within the contemporary quest for methodology in a hermeneutics of pastoral care and encounter, I wish to advocate that pastoral theology cannot operate without the correlation between biblical texts and human contexts.

Indien die hermeneutiese ontwikkeling in die pastoraat ernstig geneem word, word ontdek dat daar wel 'n verweefde verhouding bestaan tussen die temas, perspektiewe en insigte van die oudste Bybel tekste en die hedendaagse praktyk. In dié soeke na die passing tussen Bybelse tekste en menslike kon-teks(te), skryf Ganzevoort en Visser (2007:235) tereg:

De relatie inspireert en maakt het zinvol om pastoraat juist ook in bijbelse termen te beschrijven. Het gaat er daarbij om het bijbelverhaal en de verhalen van mensen niet tegen elkaar uit te spelen, maar te ontdekken hoe in het levensverhaal allerlei 
bijbelse thema's al gestalte hebben gekregen ... Het vormt de basis voor een vorm van pastorale interventie waarin het bijbelverhaal een grote rol speelt.

In die artikel word enersyds verdere ondersoek ingestel na die bepaalde teoretiese ontwikkelings, maar andersyds word daar ook in 'n sirkulêre beweging aan die hand van sketse vanuit die Lukasevangelie en met besondere klem op die Saggeusverhaal aangetoon hoe 'n narratiewe pastorale betrokkenheid (Müller, 1996:15) verbeeld kan word. Die motivering van die keuse van die Lukasevangelie word gebaseer op die volgende: In sy boek Spiritual landscape: images of the spiritual life in the Gospel of Luke wys Resseguie (2004:ix) daarop dat Lukas “... uses the physical, social, and economic landscapes of the Gospel to develop and elaborate the contours of the spiritual life". In hierdie waarneming vind die navorsers betekenis vir 'n moontlike passing met die narratiewe landskap van die mens en hoe dit in besonder in die pastoraat gekaart word. In sensitiwiteit vir die ontwikkeling van die reisplan van die geestelike lewe kaart die Saggeusverhaal die ontwikkeling van 'n narratiewe pastorale betrokkenheid waarin betekenisvolle verandering in 'n gemarginaliseerde se lewe verbeeld word. Bewus daarvan dat 'n verskeidenheid Bybelkarakters se lewensverhale sekerlik die reliëf en kontoere van 'n narratiewe pastorale betrokkenheid kan vertoon, spreek die keuse van hierdie Evangelie en betrokke teks egter ook van die navorser(s) se eie subjektiewe betrokkenheid by die Teks. Tereg erken Veltkamp dié gegewe wanneer hy sê: "Hij (die pastor) is zyn eigen verhaal. Dat spelt, of die pastort dat nu wil of niet, en of hij het zich bewust is of niet, een belangrijke rol in zijn luisteren naar de verhalen van anderen."

In die verweefdheid van Teks en lewensteks word 'n sensitiwiteit ontwikkel vir die moontlikheid dat "... the ideas we have about the world are not exact replicas, not pictures or maps of the 'real' world, but instead are constructs, or perceptions of the world which we build in our minds as we encounter the world" (Lester, 1995:31). In hierdie ruimte van ontmoeting en betrokkenheid by verskillende $\mathrm{T}(\mathrm{t})$ ekste word intertekstualiteit verwoord “... as the result of the collision and influence of everything we have ever heard, read and experienced. Every text is a mosiac or tissue of quotations" (Whiteley, 2003:162-163). Indien 'n eie subjektiewe interpretasie van Teks(te) erken kan word, word 'n eie verstaanshorison ook oopgestel vir ander se verstaansaksente en vir die moontlikheid dat dit 'n eie verstaan van $\mathrm{T}(\mathrm{t})$ ekste mag informeer en selfs mag wysig. Die koördinate vir só 'n posisie-inname in die pastoraat sou gekaart kon 
word in die konsep van subjektiewe integriteit (Van den Berg, 2006: 168).

In die dokumentering van die navorsing vanuit hierdie raamwerk word met 'n sirkulêre beweging onder meer verwys na 'n model waarin 'n integrasie van praktyk en teorie geïntegreer word tot nuwe betekenis vir die praktyk (Müller, 1996:1). Paradigmatiese, epistemologiese en metodologiese aspekte word hierdeur aan die woord gestel en aan die hand van die volgende opskrifte gestruktureer: agtergrond tot 'n pastorale betrokkenheid, 'n pastorale betrokkenheid wat spiraal en verhale wat pas.

\section{Agtergrond tot 'n ontmoeting}

In die ontginning van die Saggeusverhaal vir moontlike gebruik in 'n pastoraat van narratiewe betrokkenheid, word bepaalde paradigmatiese, epistemologiese en metodologiese kontoere gekaart. In die kartering hiervan word gevra na die invloed en betekenis van 'n paradigmatiese plasing en die betekenis van epistemologiese en metodologiese keuses.

'n Paradigma is 'n verwysingsraamwerk, 'n vertrekpunt van waaruit 'n mens dink en optree en wat 'n mens se perspektiewe en oortuigings bepaal. Van Rensburg (2000:1) gebruik die metafoor “... a frame of mind ..." as beskrywend van 'n paradigma. Metafories kan 'n paradigma as die raam gesien word wat die skildery omsluit en die karakter daarvan bepaal. Die paradigma waarbinne 'n mens werk, bepaal dus die funksionering van 'n wêreldbeskouing en die strukturering van kennis oor die wêreld en die lewe. Binne 'n modernistiese paradigma sal wetenskaplike bewyslewering en die sukses van die wetenskap bepalend wees vir só 'n wêreldbeskouing (Becvar \& Becvar, 1996:4). In 'n postmoderne paradigma daarenteen, word die beskouing gehuldig dat kennis nooit absoluut is nie, maar kontekstueel en met 'n subjektiewe aksent verstaan behoort te word (Van den Berg, 2006:172). Daarom kan Whiteley (2003:161) skryf dat:

Philosophically speaking, what potsmodernism has brought to light is that while objective truth may exist, we as human beings can only know it subjectively. This is a radical departure from previous notions of truth and authority.

Die betekenis van hierdie veronderstelling is onder meer dat die moontlike betekenis van die Saggeusverhaal in die Lukasevangelie vir die pastoraat nie net slegs met behulp van erkende eksegetiese 
metodiek aan die woord gestel moet word nie, maar dat erkenning ook gegee moet word aan die verstaanshorison(ne) van die leser.

Dat daar 'n verweefde verhouding tussen onderskeidelik paradigma, epistemologie en metodologie bestaan, blyk duidelik uit die woorde van Van Rensburg (2000:2): "The frame of mind (paradigm) determines the painting, while the epistemology is the theory of how the paint should be organised on the canvas to fit the paradigm." In die kennisname van nuwere ontwikkelings in die pastorale teologie met die klem op die hermeneutiese pastoraat, word die navorsing epistemologies binne 'n pastoraat van narratiewe betrokkenheid geplaas met die klem op "... betrokkenheid by die totale narratiewe werklikheid wat ter sprake is" (Müller, 1996:15).

Ten einde die metafoor van die skildery se betekenis verder uit te brei sou die medium, byvoorbeeld water- óf olieverf wat vir die skildery gebruik word, vergelyk kon word met die bepaalde metodologie wat in die navorsing sigbaar word. In die gereflekteerde navorsing word gekies vir 'n kwalitatiewe aksent met die klem op die soeke na die betekenis van die narratief(we) ter sprake.

Die betekenis hiervan vir navorsing is onder meer dat paradigma, epistemologie en metode van mekaar afhanklik is en rekursief op mekaar inspeel. Geloofwaardige en konsekwente navorsing sal dus 'n belyning van paradigmatiese, epistemologiese en metodologiese aksente veronderstel. Vanuit die eie pastorale praktyk en ervaring eggo die navorsing die moontlike passing van die Lukasevangelie, en in besonder die Saggeusverhaal, in die pastoraat as voorbeeld van 'n geïntegreerde wetenskaplike aanpak waarin kongruente paradigmatiese, epistemologiese en metodologiese aksente gekaart word. Die passing van Teks en lewensteks “... examines especially the physical, social and economic landscapes of the Gospel and the ways they contribute to our understanding of the Christian spiritual life. Settings can highlight the religious, mental, moral, social, and emotional landscapes of the characters" (Resseguie, 2004:5).

\section{Ontwikkelings tot 'n eko-hermeneutiese benadering en 'n pastoraat van narratiewe betrokkenheid}

Gedurende die twintigste eeu het Pastorale Terapie bepaalde ewolusionêre ontwikkelings vertoon. 'n Kerugmatiese, terapeutiese, en sedert die sewentigerjare, 'n nuwe hermeneutiese fase waarin teologie en terapie in 'n bipolêre verhouding staan, word onderskei (Foskett \& Lyall, 1988:49-50; Scholtz, 2005:141). In die ontwikkeling van die pastorale teorievorming kan verskillende paradigmatiese 
bewegings aangedui word (Müller, 1996:7-17; Louw, 1999:23-29; Louw, 2005:7-9). Ten eerste is daar 'n beweging van 'n eensydige verkondigingsmodel na 'n deelnemende pastoraat waar die pastor instrumenteel is in die begeleiding van mense tot die ontdekking van God se betrokkenheid in hulle lewe. Die verrekening van konteks en 'n verskuiwing weg van die eensydige professionele benadering tot die onderlinge versorging van gelowiges word hierin verteenwoordig. ' $n$ Volgende beweging is van 'n terapeutiese na 'n hermeneuties-georiënteerde pastoraat met klem op

... the endeavour to read, understand and interpret texts within contexts. Hermeneutics underlined anew the importance of our human quest for meaning ... (and) the importance of compassion: the dimension of pathos in theology (Louw, 2003:54).

In die terapeutiese pastoraat is baie klem geplaas op insigte vanuit die Sielkunde, terwyl die hermeneutiese pastoraat minder vra vir die verklaring van probleme en méér vir die verstaan en verheldering daarvan.

As 'n ontwikkeling van die hermeneutiese paradigma wat verstaan binne die konteks van die geheel beklemtoon, gaan dit in die ekohermeneutiese paradigma oor die verstaan van die geheel en die ontdekking van die betekenis van die geheelkonsep binne verskeie kontekste (Müller, 1996:14). Binne 'n eko-hermeneutiese aanpak vind die ontwikkeling van 'n model van narratiewe betrokkenheid byna vanselfsprekend plaas (Müller, 1996:15).

Besware vanuit 'n diakonologiese epistemologie aangaande die "not knowing"-posisie, naamlik dat die kliënt die finale arbiter is, dat die sosiale konteks beslissend is, dat die Skrif nie as objektiewe waarheid gehandhaaf word nie en dat verandering van mense nie ' $n$ belangrike doelstelling is nie (Van Rensburg, 2000:50), word binne 'n narratiewe pastorale epistemologie verantwoord.

Binne die narratiewe pastorale betrokkenheid word die pastor 'n deelnemer in die verhaal waarin na betekenis gesoek word en is die pastor nie die onfeilbare verteenwoordiger van die "waarheid" nie (Müller, 1996:16). Vanuit die sogenaamde "not knowing"-benadering word aanvaar dat die pastor onkundig is oor die kliënt(e) se lewe, maar as terapeut die vakkundige kenner is (Freedman \& Combs, 1996:44).

In die betrokkenheid by die verhaal van die ander, word die Woord nie op 'n objektiewe en outoritêre wyse deur die pastorale terapeut in die gesprek hanteer nie, maar word hermeneuties saam gesoek 
na die ontwikkeling van nuwere perspektiewe "... aan heilzame verhalen over de hand van God" (Ganzevoort, 2006:162). In die konteks van die Saggeusverhaal en binne 'n narratiewe pastorale betrokkenheid, beteken dit dat saam met Saggeus gesoek word na sy verstaan van die waarheid vir die lewe. Die betekenis van die Skrif bly in hierdie soeke rigtinggewend en daar word gestreef na 'n fusie, passing of samesmelting van die lewensverhaal/-verhale met die verhaal van die Skrif (Veltkamp, 1988:199).

Dit is in die soeke na die passing van $\mathrm{V}(\mathrm{v})$ erhale dat die verband tussen die sogenaamde objektiewe en subjektiewe aksente ter sprake kom. Tereg wys Lester (1995:31) daarop dat "[i]n Western culture we have assumed that an objective reality exists, and our theories and perceptions can accurately reflect it. In this century, however, researchers are increasingly aware that reality is not as objective as imagined." Hierin word die volgende duidelik:

It identifies truth that might potentially exist, but which cannot be accessed directly and without mediation. All perception involves interpretation, and hence any truth is an interpreted truth, reflecting the lenses of our experience. So it is a mistake to assume that we can ... somehow access some objective theological truth, unshaped by our experience, and then convey it to others who will receive it objectively. We are all shaped by our culture and experiences; they make us truly human. Truth always comes to us in a particular (rather than universal) form, and is always in conversation with the world around us. (Whiteley, 2003:162.)

In 'n verdere ontwikkeling van die aksente word 'n sosiaal konstruksionistiese verstaan van die werklikheid gebied. Dreyer (2003: 335-336) verwoord hierdie verstaan wanneer sy skryf: "Die sosiaalkonstruksionistiese model soek na die sosiale oorspronge van betekenis en fokus op diskoerse eerder as individuele eksistensie. Die sosiaal-konstruksionistiese model fokus op self-verstaan en ontwikkeling binne die sosiale konteks." Dit is in hierdie betrokkenheid by mekaar dat ons aangemoedig word "... to examine our constructions and stories - how they have come to be and what their effects are on ourselves and others" (Freedman \& Combs, 1996:35) deur onder andere daarop te let hoe verstaanshorisonne van lewe en identiteit deur die Skrif en die tradisie geïnformeer word.

Müller (1994:27) kenskets hierdie subjek-subjek kommunikasie as "verstaan" en as "hermeneuties". Hy beskou sodanige kommunikasie as in ooreenstemming met die evangeliewoord om aan mekaar onderdanig te wees - 'n opdrag wat slegs haalbaar is deur die ver- 
nuwende werk van die Heilige Gees. Dit kan dien as 'n balanserende teenwig vir die rol van mag in die wyse waarop gekonstrueerde idees waaraan 'n status van waarheid toegeken word mense se lewens bepaal; en dit dui ook op die onderdrukkende invloed van "... global and unitary knowledges ..." (White \& Epston, 1990:20). Hierdie sensitiwiteit hang saam met die postmodernistiese "... incredulity regarding metanarratives" (Lyotard, 1984:481). Indien gespreksgenote met integriteit by mekaar in die proses betrokke is, word ontdek dat

... the ideas we have about the world are not exact replicas, not pictures or maps of the 'real' world, but instead are constructs, or perceptions of the world which we build in our minds as we encounter the world (Lester, 1995:31).

So 'n sensitiwiteit lei onder meer daartoe dat kliënt en terapeut ontdek dat eie konstruksies dikwels bepaal hoe probleme verstaan word, eerder as dat die probleme bepaal wat die terapeute sien (Speed, 1991:399).

In erkenning van die subjektiewe betrokkenheid by die verskillende $\mathrm{T}(\mathrm{t})$ ekste van die lewe en in antwoord op die beswaar vanuit die diakonologie oor die miskenning van die objektiewe waarheid van die Skrif, sou dus gevra kon word na die Skrif se stem in 'n pastoraat van narratiewe betrokkenheid. Betekenisvol vir die aanhoor van die Skrif se stem binne hierdie navorsing, is die woorde van Van Huyssteen (1989:773-774) dat deur 'n pastorale narratiewe epistemologie te volg, die normerende aard van die Skrif erken word, maar dat die betekenis daarvan in verskillende kontekste getoets word. In aansluiting by hierdie perspektief wys Lester (1995:31), in navolging van die gesinsterapeut Bebe Speed, op 'n posisie "... that takes both objective reality and subjective construction seriously. His perception of this connection between the constructing knower and the reality that must be known is called 'coconstructivism'". Oor die betekenis hiervan en ter illustrering waarom die Lukasevangelie en in besonder die Saggeusverhaal in die pastoraat as voorbeeld gebruik word, kan saam met Scheffler (1992:69) gestem word dat Lukas se begrip van naasteliefde so omvattend is dat dit 'n aktualiteit verkry wat op meer kontekste van toepassing kan wees. Te midde van en met erkenning aan die verskillende diskoerse wat 'n rol speel, kan die werklikheid wat die Skrif konstrueer dus steeds normgewend in 'n narratiewe pastorale betrokkenheid wees. Ter illustrering van die funksionering van die Saggeusverhaal binne 'n pastoraat van narratiewe betrokkenheid, word die volgende dwarssnit gebied. 


\section{Dekonstruksie as pastoraal-narratiewe ingesteldheid}

Die terapeutiese betekenis en waarde van dekonstruksie word deur Becvar en Becvar (1996:89) beskryf as "... the goal is to deconstruct 'facts' by delineating the assumptions, values and ideologies upon which they rest and to consider ourselves and our constructions about life and living with skepticism and even perhaps humor". Dekonstruksie as die ontdekking en analisering van oortuigings, idees en praktyke van die breër kultuur waarbinne 'n persoon leef, en wat bydra om die probleem(storie) te versterk (Morgan, 2000:45), word treffend in die Saggeusverhaal geïllustreer:

Zacchaeus was lost: at the margins of society, a 'sinner', a Dives whose spiritual values were oriented to the self, not to the kingdom. His impoverished spirituality was determined by material values that placed him at odds with his community and with the ethics of the kingdom of God ... Jesus' acceptance of Zacchaeus brings the tax collector from the margins to the foreground ... Zacchaeus relinquishes control of his wealth and abandons the dropsical drive to accumulate. (Resseguie, 2004: 109.)

In die konteks van die Saggeusverhaal kan die godsdiensgemeenskap se negatiewe siening van tollenaars, as 'n "constructed idea" met 'n waarheidstatus wat dit 'n "uitgeworpe beroep" verklaar, geïdentifiseer word (Scheffler, 1992:68). Die problematiek van Saggeus se versadigde dominante lewensverhaal word onder meer verder in stand gehou deur sy materialistiese smagting en in watter mate sy eie rykdom 'n bydrae lewe tot die verarming van ander (Resseguie 2004:108). Die posisie van Saggeus word nog verder in die teks van Lukas 19 gemarginaliseer deur ten minste twee grense, naamlik sy kort lengte en die groot skare wat hom van Jesus weghou (Resseguie 2004:19).

In die verhaal in Lukas 19 word egter opgemerk hoe Jesus met sy tuiskoms in Saggeus se huis geykte gesindhede dekonstrueer, wat “... ('n) alternatiewe storie ... na vore ... bring” (Van Heerden \& Kotze, 1997:89). Wanneer die narratief in 'n geloofsbedding vloei (Gerkin, 1986:19), soos by Saggeus, word "die isolasie van die eie vasgeloopte situasie in die hede deurbreek" (Van Rensburg, 1996: 75). Saggeus se kennis van die Messias het as kragtige, unieke uitkoms sy geloof in geestelike waardes vernuwe, sy verbondsgekoppelde ewigheidsbesef versterk, en die wesenlike waarde van sy godsdienstige erfgoed bevestig. Die unieke uitkomservaring is versterk deur die verrassende uitsprake van die Meester, en het oorwinningskrag wat moeilik bereikbaar was in die lig van die 
probleem, transformerend in sy lewe na vore laat kom (Morgan, 2000:52). Nuwe insig in ou geestelike waarhede, wat deur 'n oppervlakkige lewensuitkyk verbloem was, open vir Saggeus die deurgang tot 'n alternatiewe storie. Deur herformulering van die verhaal word "ander, nuwe betekenisse aan gebeure toegeken" (Müller, 2000:93). Hierin word die ontwikkeling in die pastorale teorievorming ook gekaart. Van die aanvanklike klem op die rol van sonde in die kerugmatiese model en die premie op menslike kapasiteit in die terapeutiese model word die klem nou in die hermeneutiese pastoraat op die relasionele begrip van versoening geplaas (Ganzevoort \& Visser, 2007:2342).

Dekonstruksie as ingesteldheid tot 'n analiserende lees van $\mathrm{T}(\mathrm{t})$ ekste, vervul dus ' $\mathrm{n}$ hermeneutiese funksie in ooreenstemming met die epistemologiese uitgangspunte van hierdie studie. Sodoende is dekonstruksie meer as die bou van 'n nuwe identiteit in 'n eie bevrydingsgeskiedenis; dit is, soos by Saggeus, instrumenteel om die mens eskatalogies na 'n oorwinningslewe in Christus te rig (Van Heerden \& Kotze, 1997:91). Hierdeur word wegbeweeg van die reduksionistiese siening van taal as 'n stelsel op sigself. Taal word kontekstueel in die individu se besinning oor wesenlike sake benut (Dill \& Kotze, 1997:20-21). Namate unieke uitkomste of gewaarwordings, as boustene vir 'n alternatiewe storie, by Saggeus vorm aangeneem het as middele om 'n ryker beskrywing van alternatiewe stories te fasiliteer (Sirr, 2001:37), het dit gelei tot die herdefiniëring van homself en sy verhoudings met ander mense (Van Heerden \& Kotze, 1997:90). In die ontmoetings met Saggeus beweeg geloofsgroei in 'n spiraal na die konvergensiepunt wanneer die volheid van die heil in Christus beleef word (Louw, 1999:14-15). Saggeus se groei in geloofsvolwassenheid, as belangrike terapeutiese mikpunt (Louw, 1999:30), kom na vore in sy ervaring van hoop in die hantering van die probleme van skuld, angs en die belewenis van wanhoop en sinloosheid. As kriterium vir geloofsvolwassenheid geld dat die mens in staat is om ten spyte van lyding God se teenwoordigheid hermeneuties te verstaan, en in dankbaarheid vir sy liefdestrou teenoor Hom te lewe (Louw, 1999:14).

\section{Verhale wat pas}

In hierdie artikel is reeds aangetoon dat binne 'n hermeneutiesgeoriënteerde pastoraat die klem geplaas word op "... the endeavour to read, understand and interpret texts meaning ... (and) the importance of compassion: the dimension of pathos in theology" (Louw, 2003:54). In die narratiewe pastoraat as eksponent van 
hierdie hermeneutiese ontwikkeling, word byvoorbeeld gesoek na tekens van God se teenwoordigheid in die verhale van mense.

Saggeus se verhaal toon aksente van die ontwikkeling namate sy eie storie helderder belig word deur die verhaal van die evangelie (Louw, 1999:23). 'n Normatiewe dimensie (bewuswording van 'n sondige lewe) asook 'n etiese dimensie (die begeerte om reg te stel wat verbrou is) word onder meer geïmpliseer (Louw, 1999:9). Daardeur kon Saggeus beter verstaan hoe sy eie klein geskiedenis inpas en deel is van die heilsgeskiedenis (Müller, 2000:77). Die evangelie het as 't ware gespreksmatig gekonkretiseer binne sy lewenswerklikheid as gelowige mens (Louw, 1999:35). Dit het vir hom die verbintenis tussen sy unieke storie en die Christusverhaal bevestig (Gerkin, 1997:111). Vanuit 'n verduisterde verledeverhaal word ruimte geskep vir 'n toekomsverhaal van hoop (Müller, 1996: 111-139). Die verbinding tussen die verhale het die fundamentele pastorale sorgdoel van die pastorale proses vervul (Gerkin, 1997:110-112). Daarin staan die verbond as 'n konkrete ontmoetingsgebeure, reeds êrens in die ver verlede, wat heenwys na God se uitreiking na hom (Louw, 1999:92). Eko-hermeneuties maak die verbond deel uit van ' $\mathrm{n}$ veelheid van faktore en diskoerse (Müller, 1996:14), maar met uitsonderlike betekenis as bydrae tot die sin en betekenis in die verhouding met God binne die menslike leefkonteks (Louw, 1999:22, 23).

\section{Samevatting}

In die reis van die Lukasevangelie word verskillende stasies van spirituele vorming besoek. Een bestemming is wanneer

Luke offers a way out of the cycle of plenty and consumption. Zacchaeus discovered that life is not found in the accumulation of possessions but in the dispossession of his abundance. Before he met Jesus, his material values determined his spirituality; after Jesus, his spiritual values determined his material values. He placed his wealth in the service of the poor and made right the wrongs he had committed. (Resseguie, 2004:114.)

Die Evangelie van Lukas verbeeld 'n spirituele reis na 'n nuwe beloofde land, naamlik die Koninkryk van God. In die pastoraalnarratiewe paradigmatiese, epistemologiese en metodologiese uitgangspunte, wat aan die hand van die Saggeusverhaal gekaart is, is aangetoon hoe 'n dominante lewensreis in 'n pastoraat van nar- 
ratiewe betrokkenheid omskep kan word in 'n alternatiewe bestemming met nuwe betekenis.

\section{Geraadpleegde bronne}

BECVAR, D.S. \& BECVAR, R.J. 1996. Family therapy: a systemic integration. 3rd ed. Londen: Allyn \& Bacon.

DEMASURE, K. \& MÜLLER, J. 2006. Perspectives in support of the narrative turn in pastoral care. Nederduitse Gereformeerde teologiese tydskrif, 47(34):410-419.

DILL, J. \& KOTZE, D.J. 1997. Verkenning van 'n postmoderne epistemologiese konteks vir die praktiese teologie. Acta theologica: 17(1):1-26.

DREYER, Y. 2003. Luister na die storie van die kerk: riglyne vanuit 'n narratiefhermeneutiese perspektief. Hervormde teologiese studies, 59(2):333-351.

FOSKETT, J. \& LYALL, D. 1988. Helping the helpers: supervision and pastoral care. London: SPCK.

FREEDMAN, J. \& COMBS, G. 1996. Narrative therapy: the social construction of preferred realities. New York: Norton.

GANZEVOORT, R. 2006. De hand van God en andere verhalen: over veelkleurige vroomheid en botsende beelden. Zoetermeer: Meinema.

GANZEVOORT, R. \& VISSER, J. 2007. Zorg voor het verhaal: achtergrond, methode en inhoud van pastorale begeleiding. Zoetermeer: Meinema.

GERKIN, C.V. 1986. Widening the horizons: pastoral responses to a fragmented society. Philadelphia: Westminister.

GERKIN, C.V. 1997. An introduction to pastoral care. Nashville: Abingdon.

IMMINK, F.G. 2003. In God geloven: een praktisch-theologische reconstructie. Zoetermeer: Meinema.

LESTER, A.D. 1995. Hope in pastoral care and counselling. Louisville: Westminister John Knox Press.

LOUW, D.J. 1999. Pastoraat as vertolking en ontmoeting. Wellington: LuxVerbi.

LOUW, D.J. 2003. The paradigmatic revolution in practical and pastoral theology: from metaphysics (sub-stansial thinking) to empirism (experential thinking); from Theism to Theopaschitism (hermeneutical thinking). Practical theology in South Africa, 18(2):33-57.

LOUW, D.J. 2005. Paradigm shifts and new perspectives on anthropology in pastoral care and counselling: cura animarum as cura vitae. Ongepubliseerde lesing gelewer tydens die 18de Seminaar van die Society for Intercultural Pastoral Care and Counselling 2-7 October 2005, Düsseldorf, Germany.

LYOTARD, J.F. 1984. The postmodern condition: a report on knowledge. Cambridge: Blackwell.

MORGAN, A. 2000. What is narrative therapy? Adelaide: Dulwich.

MÜLLER, J.C. 1994. Practical theological wisdom in the context of pastoral marriage and family therapy. Practical theology in South Africa, 9(1):2028.

MÜLLER, J.C. 1996. Om tot verhaal te kom. Pretoria: RGN-Uitgewers.

MÜLLER, J.C. 2000. Reis-geselskap. Wellington: Lux Verbi.BM.

MÜLLER, J.C. 2005. A postfoundationalist, HIV-positive practical theology. Practical theology in South Africa, 20(2):72-88. 
RESSEGUIE, J.L. 2004. Spiritual landscape: images of the spiritual life in the Gospel of Luke. Massachusetts: Hendrickson.

SCHEFFLER, E. 1992. Naasteliefde in die Lukas-Handelinge. Scriptura: tydskrif vir Bybel en teologie in Suider-Afrika. Spesiale Uitgawe, S9a: 55-73.

SCHOLTZ, E. 2005. Pastorale benaderings: 'n herbeskrywing vanuit 'n narratiewe perspektief. Praktiese teologie in Suid-Afrika, 20(20):140-152.

SIRR, R. 2001. Key learnings after two weeks. Dulwich centre journal, (3 \& 4):37-38.

SPEED, B. 1991. Reality exists O.K.? An argument against constructivism and social constructionism. Family process, 30:395-409.

STONE, H.W. 2001. The congregational setting of pastoral counselling: a study of pastoral counselling theorists from 1949-1999. The Journal of pastoral care, 55(2):181-196.

VAN DEN BERG, J.A. 2006. 'n Verandering in tongval? 'n Verwoord- (-beeld-)ing van pastoraal-teologiese perspektiewe. Praktiese teologie in SuidAfrika, 21(2):164-181.

VAN HEERDEN, P.R. \& KOTZE, D.J. 1997. Die pastorale gesprek binne 'n narratiewe diakonale pastoraat. Acta theologica, 1:81-98.

VAN HUYSSTEEN, W. 1989. Narrative theology: an adequate paradigm for theological reflection? Hervormde teologiese studies, 45(4):767-777.

VAN RENSBURG, J.J. 1996. Regterbrein-strategieë vir pastorale terapie. Nederduitse Gereformeerde teologiese tydskrif, 39(1 \& 2):65-78.

VAN RENSBURG, J.J. 2000. The paradigm shift. Pretoria: Van Schaik.

VELTKAMP, H.J. 1988. Pastoraat als gelijkenis. Kampen: Kok.

WHITE, M. \& EPSTON, D. 1990. Narrative means to therapeutic ends. New York: Norton.

WHITELEY, R.J. 2003. "Woo me, sister; move me, brother!" What does pop culture have to do with preaching. (In Whiteley, R.J. \& Maynard, B., eds. Get up off your knees: preaching the U2 catalog. Cambridge: Cowley. p. 157-165.)

\section{Kernbegrippe:}

epistemologie

metodologie

narratief

paradigma

pastoraat

Saggeus

\section{Key concepts:}

epistemology

methodology

narrative

paradigm

pastoral care

Zacchaeus 
